\title{
Serology for Toxoplasmosis and Neosporosis in Ewes in the State of Mato Grosso Do Sul, Brazil
}

Leandra Marla Oshiro', Fernando Alvarenga Reis ${ }^{2}$, Rosangela Locatelli Dittrich ${ }^{3}$, Rodrigo Casquero Cunha ${ }^{4}$ and Renato Andreotti ${ }^{2 *}$

${ }^{1}$ Post Graduate Program in Infectious and Parasitic Diseases, Universidade Federal do Mato Grosso do Sul, Brazil

${ }^{2}$ Embrapa Beef Cattle, Av. Rádio Maia no. 830, Zona Rural, CEP 79106-550, Campo Grande, MS, Brazil

${ }^{3}$ Department of Veterinary Medicine, Universidade Federal do Paraná, Brazil

${ }^{4}$ Department of Biotechnology, Universidade Federal de Pelotas, Brazil

\begin{abstract}
Toxoplasma gondii and Neospora caninum are protozoans that can cause reproductive problems in sheep. The aim of the present study was to determine the frequency of anti- $N$. caninum and anti- $T$. gondii antibodies among sheep herds in some counties in the state of Mato Grosso do Sul. Four hundred sixteen serum samples were collected from ewes in eight counties. The sera samples were evaluated by using an indirect fluorescent antibody test with a 1:50 dilution. The seroprevalences found for $T$. gondi and $N$. caninum were $33.7 \%$ and $52.2 \%$, respectively. The rate of animals testing positive simultaneously for Neospora and Toxoplasma was of $17.5 \%$. The results of the present study demonstrate that sheep raised in these counties are exposed to T. gondii and $N$. caninum and that sheep can be co-infected with both parasites.
\end{abstract}

Keywords: Coccidia; Parasitic disease; Serology; Indirect immunofluorescence; Reproductive problems

\section{Introduction}

Toxoplasmosis is caused by the Toxoplasma gondii and Neosporosis by the Neospora caninum. Both parasites are protozoans of the Sarcocystidae family and have a wide geographic distribution. There are reports of anti-T. gondii and anti-N. caninum antibodies in several species, including humans [1]. The definitive hosts of T. gondii are felids, and the definitive hosts of $N$. caninum are certain canids, such as the domestic dog, the wolf and the coyote [2-6]. The relevant intermediate hosts of $T$. gondii and $N$. caninum are livestock, such as sheep, cattle and goats [2]. These parasites may cause abortions and stillbirths [7], and, consequently, economic losses. Studying the intermediate hosts may help to identify $T$. gondii and $N$. caninum circulation patterns in different environments [8].

Brazil has favorable geographical and climatic conditions for sheep production. Its current sheep population is estimated to be 16.789 .492 animals [9], with the state of Mato Grosso do Sul (MS) having 498.064 animals. Even though sheep breeding never became an economic activity of equal importance as cattle breeding, sheep meat has always been part of the Mato Grosso do Sul population's diet. The sheep's economic importance increased with the arrival of immigrants who had the tradition of lamb meat consumption, such as the gaúchos, northeastern Brazilians and Syrian-Lebanese. In Campo Grande, 92\% of consumers have tried lamb meat, and most have a favorable opinion about it [10].

The Mato Grosso do Sul state was studied by Andreotti et al. [11], Marques et al. [12] and Pinto et al. [13], who reported the presence of anti-N. caninum and - T. gondii antibodies in sheep, using different techniques and obtaining different results. Other diseases related to abortion were mentioned by Juliano et al. [14] in the municipality of Corumbá. They found a $12.8 \%$ seropositivity for ovine brucellosis in a herd of 1.198 animals, through the use of the IDGA method. In the Nhecolandia region, also in the municipality of Corumbá, wild and domestic animals sera (including ovines) were analyzed for antibody titles against serological variants of leptospira, and it was found that $9 \%$ of animals were contaminated, in a group of 110 [15].
In Mato Grosso do Sul, sheep breeding is usually done extensively, being a secondary activity to cattle breeding; the production is mainly used for the farmer's own consumption [16]. Nonetheless, the production system has been changing over the years, but disease reports are still low in the state.

Considering the data previously reported, showing that the toxoplasmosis may be a source of infection for humans and that neosporosis may cause abortion, and that currently there are few reports about the infection of these parasites in sheep in the state of Mato Grosso do Sul, the objective of this study was to verify the occurrence of infection by $T$. gondii and $N$. caninum in sheep from farms located at the intersection of the four mesoregions of the state of Mato Grosso do Sul.

\section{Material and Methods}

\section{Animals and samples}

Blood samples were collected in 2010 from 410 ewes of reproductive age, each having several offspring. The blood samples $(5.0 \mathrm{~mL})$ were stored in tubes without anticoagulant. The serum was separated by centrifugation and stored at $-20^{\circ} \mathrm{C}$, until the analysis was done. The samples were collected in the most representative region (comprising 79 counties; Table 1) regarding the presence of flocks in the state of Mato Grosso do Sul, Brazil (Figure 1).

The study was conducted in counties belonging to 03 of 04

*Corresponding author: Renato Andreotti, Embrapa Beef Cattle, Av. Rádio Maia no. 830, Zona Rural, CEP 79106-550, Campo Grande, MS, Brazil, Tel: 55673368 2173; E-mail: Renato.andreotti@embrapa.br

Received April 07, 2015; Accepted May 27, 2015; Published May 29, 2015

Citation: Oshiro LM, Reis FA, Dittrich RL, Cunha RC, Andreotti R (2015) Serology for Toxoplasmosis and Neosporosis in Ewes in the State of Mato Grosso Do Sul, Brazil. J Veterinar Sci Technol 6: 233. doi:10.4172/2157-7579.1000233

Copyright: @ 2015 Oshiro LM, et al. This is an open-access article distributed under the terms of the Creative Commons Attribution License, which permits unrestricted use, distribution, and reproduction in any medium, provided the original author and source are credited. 
Citation: Oshiro LM, Reis FA, Dittrich RL, Cunha RC, Andreotti R (2015) Serology for Toxoplasmosis and Neosporosis in Ewes in the State of Mato Grosso Do Sul, Brazil. J Veterinar Sci Technol 6: 233. doi:10.4172/2157-7579.1000233

Page 2 of 5

\begin{tabular}{|c|c|c|c|c|c|}
\hline \multirow{2}{*}{ Counties (n) } & \multicolumn{2}{|c|}{ Neospora caninum } & \multicolumn{2}{|c|}{ Toxoplasma gondii } & \multirow{2}{*}{$\begin{array}{c}\text { Chi-square } \\
\text { P-value }\end{array}$} \\
\hline & Positive & Frequence & Positive & Frequence & \\
\hline Anaurilandia (46) & 16 & $34.8 \%$ & 32 & $69.6 \%$ & $p=0.0914$ \\
\hline Caarapo (05) & 2 & $40.0 \%$ & 3 & $60.0 \%$ & $p=0.1921$ \\
\hline Campo Grande (49) & 25 & $51.0 \%$ & 8 & $16.3 \%$ & $p=0.6997$ \\
\hline Eldorado (241) & 135 & $56.01 \%$ & 64 & $26.6 \%$ & $p<0.0001$ \\
\hline Fátima do Sul (19) & 10 & $52.6 \%$ & 12 & $63.2 \%$ & $p=4371$ \\
\hline Maracaju (05) & 1 & $20.0 \%$ & 5 & $100 \%$ & $p=0.3711$ \\
\hline Nova Andradina (26) & 18 & $69.2 \%$ & 10 & $38.5 \%$ & $p=0.6143$ \\
\hline Sidrolandia (19) & 7 & $36.8 \%$ & 4 & $21.1 \%$ & $p=0.2312$ \\
\hline Total (416) & 214 & $52.2 \%$ & 138 & $33.7 \%$ & $p<0.0001$ \\
\hline
\end{tabular}

Table 1: Frequence of positive serum for T. gondii and N. caninum in sheep in the state of Mato Grosso do Sul, Brazil.

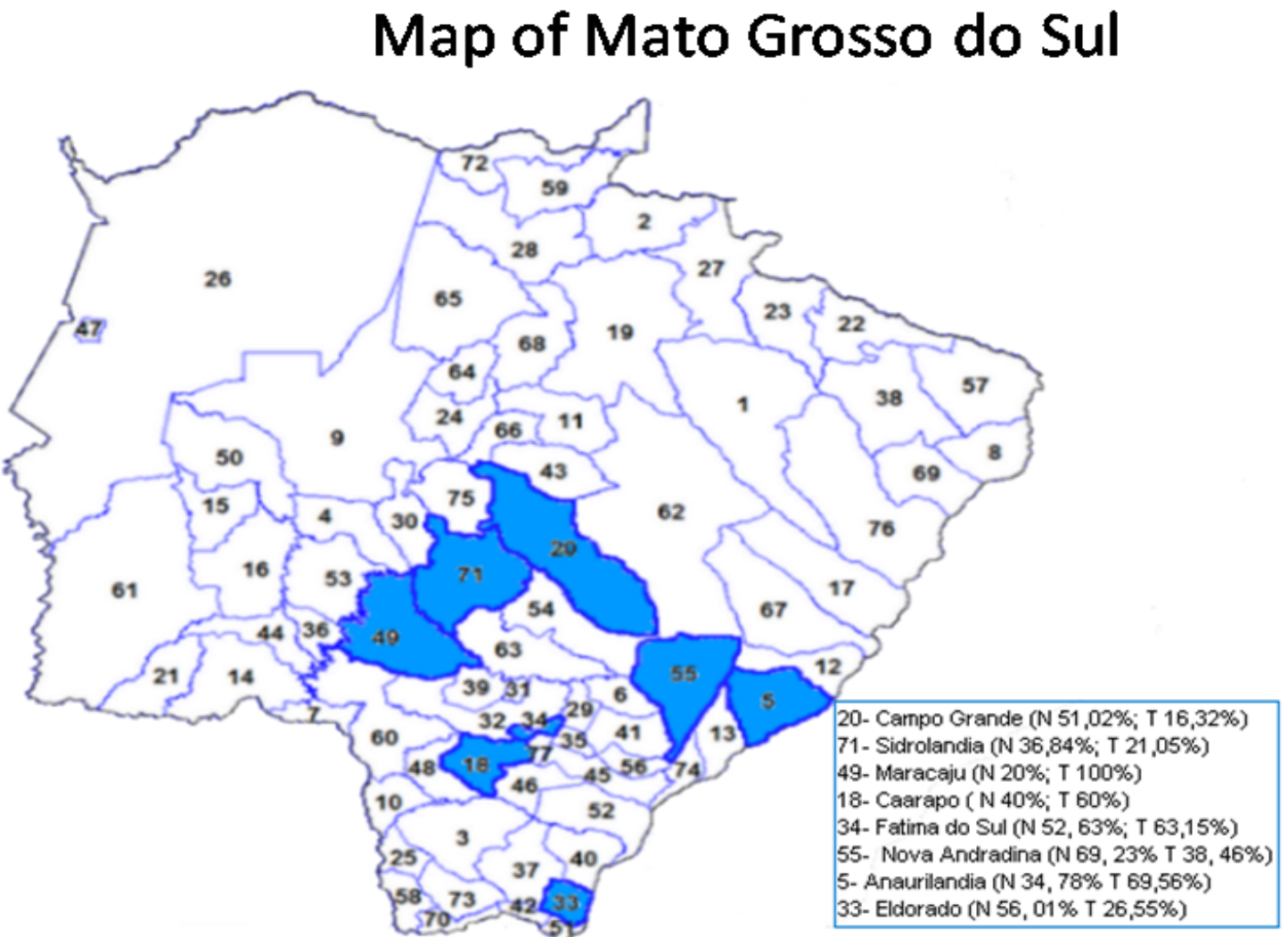

Figure 1: Map of Mato Grosso do Sul State, Brazil with the sampled counties and the frequency of positive serum for Neospora caninum (N) and Toxoplasma gondi (T).

mesoregions, according to IBGE/CIDER [9]. These are the mesoregions with the highest sheep population in the state of Mato Grosso do Sul. The city of Campo Grande, where the only slaughterhouse in the state is located, is within one of these mesoregions.

For the purpose of epidemiological representation and adequate statistical analysis, the non-probability sampling method was used to select the producers. This decision was taken due to the small number of sheep producers in Mato Grosso do Sul, which impairs the use of random sampling.

The available literature regarding the mentioned parasites in the Mato Grosso do Sul state is small. One of the studies reported the inexistence of the T. gondii in sheep from the municipality of Eldorado
[12]. Regarding the N. caninum, antibodies were found in $30.8 \%$ of the sheep tested [11].

The minimum number of samples to be tested (n) was statistically calculated [17] considering an expected prevalence of 5\% (based on the lowest prevalence found in the literature for the studied region and considering both diseases), a sampling error of $20 \%$ and a confidence level of $95 \%(\mathrm{z}=1.96)$, the number of samples to be tested was calculated at 410 .

\section{Serological diagnosis}

The indirect fluorescent antibody test (IFAT) was used to detect anti-T. gondii and anti-N. caninum antibodies, according to the methods described by Camargo [18] and Dubey et al. [19] respectively. 
According to Dubey and Lindsay [7], for each serological test in each region, there are several serological techniques and various cutoff, so there are several positive values.

The T. gondii $\mathrm{RH}$ and $N$. caninum $\mathrm{NC}-1$ strains were used as antigens in the IFAT. N. caninum tachyzoites were maintained in Vero cell cultures, and T. gondii tachyzoites were obtained by intraperitoneal passage in mice. At the Embrapa Gado de Corte laboratory, the antigens were processed and maintained in Vero cell cultures [20,21] at $37^{\circ} \mathrm{C}$ and without $\mathrm{CO}_{2}$.

The sera dilution used for the IFAT was 1:50 [22,23]. Positive and negative control sera were used on each slide. The secondary antibody used was the monoclonal FITC-conjugated anti-sheep IgG (SigmaAldrich F 5137) at a 1:160 dilution. Samples with complete peripheral fluorescence, when viewed under immunofluorescence microscopy, were considered positive [22].

\section{Statistics}

The Chi-square test was applied to statistically differentiate the seroprevalence between counties and in the total sample.

\section{Results and Discussion}

Of the 416 samples examined in the present study, $52.2 \%$ and $33.7 \%$ were positive for N. caninum and T. gondii, respectively $(\mathrm{p}<0.0001$; Table 1). These results show that $N$. caninum is highly distributed among the sheep population. Across the counties studied, there were animals contaminated simultaneously with $N$. caninum and T. gondii; however, the simultaneous seroprevalence rate was low $(17.5 \%$; 73/416).

In all the counties studied, there was at least one animal contaminated with N. caninum or T. gondii. The municipality of Nova Andradina had the highest prevalence of anti- $N$. caninum antibodies (69.2\%). Maracaju city had the highest prevalence of anti-T. gondii (100\%) and the smallest of anti-N. caninum (20\%), but there was no statistically significant difference $(\mathrm{p}=100 \%$; Table 1$)$, probably because of the small sample(5 samples). The county of Campo Grande had the smallest seroprevalence for $T$. gondi (16.3\%).

Serology studies of the presence of anti-N. caninum and -T. gondii antibodies have been made in various parts of the world and in Brazil. However, it is hard to compare the results due to different cutoff points and methods used for diagnosis [1,24].

There are several serological methods to evaluate the presence of antibodies against T. gondii and N. caninum in sheep. One of the most used is the IFAT, although other methods are also suitable for analyzing different animal species $[25,26]$.

A study conducted in Jaboticabal, state of São Paulo, found, through the use of IFI, an anti-T. gondii antibody prevalence of $52.05 \%$ (254/488). This high prevalence was associated with the presence of felids, directly related to the spread of oocysts in the properties studied; the importance of sheep in T. gondii transmission to humans was emphasized [27]. Therefore, the T. gondii rate of contamination in Jaboticabal was higher than the one found in this study $(33.7 \%$; 138/416); the difference is that this one included several municipalities [28] evaluated the presence of $T$. gondii in sheep sera in 23 municipalities of the state of Alagoas, and showed a prevalence of $32.9 \%(142 / 432)$. The results found can be considered as a base reference for this study, since the herds that were analyzed belonged to different municipalities. Although the results are similar, the studies are not comparable because of the different number of surveyed municipalities, different number of animals and the different cutoff points in each study.

In a study conducted in 04 nearby municipalities in the state of São Paulo, a survey was made to identify the presence of anti- $N$. caninum and -T. gondii antibodies. A sample of 597 animals was used, predominantly composed of female animals intended for human consumption, for the manufacture of wool and reproduction. The result found a presence rate of $34.7 \%$ for $T$. gondii and $9.2 \%$ for N. caninum [29]. This study is close to the current study because there is at least one animal that tested positive for T. gondii in each municipality studied.

Regarding T. gondii infection, Pinheiro et al. [28] reported a prevalence of $32.9 \%(142 / 432)$ in a study performed in 23 municipalities in the state of Alagoas. The results found by these authors were similar to those found in our study. Similar results were also found in a study performed in the state of São Paulo, in which 34.7\% (207/597) of the animals were seropositive and at least one animal had anti-T. gondii antibodies in all of the properties studied [29]. A study conducted in Jaboticabal, state of São Paulo, found an anti-T. gondii antibody prevalence of $52.05 \%$ (254/488), which is higher than the prevalence of the two other cited studies. This high prevalence was associated with the presence of felids in the properties studied, and the importance of sheep in T. gondii transmission to humans was emphasized [27].

The present study found a higher serology of N. caninum (52.2\%) than T. gondii $(33,7 \%)$. These data differ from those reported by Rossi et al. [30], who found a seropositivy of $47.1 \%$ for N. caninum and $46.5 \%$ for $T$. gondii. In relation to $N$. caninum, the result above is close to ours, but with a different cutoff. In the state of Pernambuco, Tembue et al. [31] reported a $N$. caninum prevalence rate of $64.2 \%(52 / 81)$ after surveying 23 properties in the municipality of Ibimirim. In the study by Tembue et al. [31], 10 males and 127 females were evaluated, and there was no significant difference between genders. In the present study, only females were assayed.

In Brazil, there is a large variation between positive and negative results for both $T$. gondii and $N$. caninum. This variation can be explained by the large sheep population, the different breeds raised in the country, the food resources available and the animal age, among other factors [32]. Ueno et al. [33] reported that different serological tests, cutoff values and sampling methods might increase the difficulty of comparing the prevalence of anti-T. gondii and anti-N. caninum antibodies between different studies performed in different regions.

Until now, there had been only three reports on the presence of anti-N. caninum and/or anti-T. gondii antibodies in sheep in the state of Mato Grosso do Sul. Among these reports, Andreotti et al. [11], in a study performed in 2008 in Campo Grande-MS, reported a prevalence of $30.8 \%$ for N. caninum (136/441) in ewes using the IFAT and indirect ELISA tests with the rNcSRS2 recombinant antigen. Andreotti et al. [11] also reported a seropositivity increase among ewes from 2008 to 2010 in the same region. The current study is the first to demonstrate the simultaneous occurrence of anti- $T$. gondii and anti-N. caninum antibodies in sheep from Mato Grosso do Sul.

Marques et al. [12] studied the presence of anti-T. gondii antibodies in sheep in Eldorado - MS, and did not find serum antibodies using the direct agglutination test $(1: 25)$. This result differs from the current study, which found a $33.7 \%$ positivity using the IFAT method (1:50).

Pinto et al. [13] reported an abortion outbreak in a herd of 268 ewes in the municipality of Aquidauana, MS. Among all the animals, 186 were ewes in the third trimester of gestation, and 10 of them 
aborted. Of the four fetuses evaluated three were from the same ewe. Immunohistochemical examination of the fetuses showed strong positive staining for $N$. caninum and weak positive staining for $T$. gondii. $N$. caninum infection was confirmed, demonstrating the importance of the N. caninum as a potential abortion agent for sheep.

\section{Conclusion}

In conclusion, our work shows that $T$. gondii and $N$. caninum infections occur in sheep of this region. In all the municipalities studied, there was at least one animal with anti-T. gondii or anti-N. caninum serum antibodies. Therefore, regular monitoring of toxoplasmosis is important due to its zoonotic potential and the reproductive disorders it can cause in ovine flocks, leading to economic losses. This is also a problem regarding neosporosis, which also has the potential to cause reproductive disorders. The high prevalence percentages of $N$. caninum and $T$. gondii should serve as a warning that the control of these diseases in sheep farming should be taken more seriously.

\section{Acknowledgments}

To the National Council for Technological and Scientific Development (Conselho Nacional de Desenvolvimento Científico e Tecnológico-CNPq) for the financial support of the project entitled "Zoo-sanitary study of tropical goat and sheep production: epidemiology, risks and economic impact of these diseases", led by Francisco Selmo Fernandes Alves, who is a researcher at Embrapa Goats and Sheep (Embrapa Caprinos e Ovinos)

To the Laboratory of Veterinary Clinical Pathology of the Federal University of Paraná (Laboratório da Patologia ClínicaVeterinária da UFPR)-Prof. Dra. Rosangela Locatelli Dittrich for giving aliquots of $T$. gondii and $N$. caninum.

To the veterinarians Verónica Teresita de Jesus Guglielmi and Carolina Faria Turquino for assisting with livestock selection and collection of the experimental samples.

\section{References}

1. Dubey JP (2003) Review of Neospora caninum and neosporosis in animals The Korean Journal of Parasitology 41: 1-16.

2. Dubey JP, Schares G (2011) Neosporosis in animals-The last five years Veterinary Parasitology 180: 90-108.

3. McAllister MM, Dubey JP, Lindsay DS, Jolley WR, Wills RA, et al. (1998) Dogs are definitive hosts of Neospora caninum. International Journal for Parasitology 28: $1473-1478$

4. King JS, Slapeta J, Jenkins DJ, AI-Qassab SE, Ellis JT, et al. (2010) Australian dingoes are definitive host of Neospora caninum. J Parasitol 40: 945-950.

5. Dubey JP, Jenkins MC, Rajendran C, Miska K, Ferreira LR, et al. (2011) Gray wolf (Canis lupus) is a natural definitive host for Neospora caninum. Veterinary Parasitology 181: 382-387.

6. Gondim LFP, Mcallister MM, Pitt WC, Zemlicka DE (2004) Coyotes (Canis latrans) are definitive hosts of Neospora caninum. International Journal for Parasitology 34: 159-161.

7. Dubey JP, Lindsay DS (1990) Neospora caninum induced abortion in sheep Veterinary Diagnostic Investigation 2: 230-233.

8. Coiro CJ, Langoni H, Silva RC, Ullman LS (2011) Fatores de risco para leptospirose, leishmaniose, neosporose e toxoplasmose em cães domiciliados e peridomiciliados em Botucatu-SP Vet e Zootec 18: 393-407.

9. IBGE-Instituto Brasileiro de Geografia e Estatistica [Brazilian Institute of Geography and Statistics].Banco de Dados Agregados [Data bank]

10. Sorio A (2009) Agribusiness system of mutton: the example of Mato Grosso do Sul merits, Passo Fundo.

11. Andreotti R, Matos MFC, Goncalves KN, Oshiro LM, Lima-Junior MSC, et al. (2009) Comparison of indirect ELISA based on recombinant protein NcSRS2 and IFAT for detection of Neospora caninum antibodies in sheep. Revista Brasileira Parasitologia Veterinaria 18: 19-22.

12. Marques JM, Isbrecht FB, Lucas TM, Guerra IMP, Dalmolin A, et al. (2009)
Anti-Toxoplasma gondii antibody detection in animals from farms of a rural community south of Mato Grosso do Sul, Brasil Semina. Cien Agr Londrina 30: 889-898.

13. Pinto AP, Bacha FB, Santos BS, Driemeier D, Antoniassi NAB, et al. (2012) Sheep abortion associated with Neospora caninum in Mato Grosso do Sul, Brazil. Pesq Vet Bras 32: 739-742.

14. Juliano RS, Silva MSP, Pellegrin AO, Lima MFNT, Silva RAMS (2011) Prevalência de brucelose ovina no município de Corumbá-MS. Veterinária Zootecnia 18: 827-830.

15. Girio RJS, Pereira FLG, Marchiori Filho M, Mathias LA, Herreira RCP, et al. (2004) Investigation of antibodies to Leptospira spp. in wild and feral animals from the region of Nhecolândia, Mato Grosso do Sul, Brazil. Use of the immunohistochemistry technique for the agent detection. Ciência Rural 34 165-169.

16. Carneiro, LOHB (2002) The cutting sheep industry in Mato Grosso do Sul: an economical alternative, Campo Grande, MS, Federal University of Mato Grosso do Sul 21.

17. Astudillo VM (1979) Sample survey populations for epidemiologic studies em animals. Manual series is Didaticos Rio de Janeiro. Pan American Center for Disease Febre 60

18. Camargo ME (1974) Introduction to immunofluorescence [ Introduction to immunofluorescence techniques ] Journal of Clinical Pathology 10: 87-107.

19. Dubey JP, Hattel AL, Lindsay DS, Topper MJ (1988) Neonatal Neospora caninum infection in dogs: isolation of the causative agent and experimental transmission. J Am Vet Med Assoc 193: 1259-1263.

20. Freshney RI (1987) Culture of animal cells: a manual of basic techniques. New York, Wiley-Liss, 397.

21. Artigas RS, Amores WG, Batista YG, Cruz AM, Valdes, DC et al. (2012) Seroprevalence of Toxoplasma gondii in blood donors of the province of Guantanamo. Revista Cubana de Plantas Medicinales 31: 101-107.

22. Paré J, Hietala SK, Thurmond MC (1995) Interpretation of an indirect fluorescent antibody test for diagnosis of Neospora sp. infection incattle. J Vet Diagn Invest 7: 273-275

23. Dubey JP (2009) Toxoplasmosis in sheep-The last 20 years. Veterinary Parasitology 163: 1-14.

24. Dubey JP, Lago EG, Gennari SM, Su C, Jones JL (2012) Toxoplasmosis in humans and animals in Brazil: high prevalence, high burden of disease, and epidemiology. Parasitology 139: 1375-1424.

25. Dubey JP, Lindsay DS, Adams DS, Gay JM, Baszler TV, et al. (1996) Serologic responses of cattle and other animals infected with Neospora caninum. Am J Vet Res 57: 329-336.

26. Shaapan RM, El-Nawawi FA, Tawfik MA (2008) Sensitivity and specificity of various serological tests for the detection of Toxoplasma gondii infection in naturally infected sheep. Vet Parasitol 153: 259-362.

27. Lopes WD, Santos TR, da Silva Rdos S, Rossanese WM, de Souza FA, et al. (2010) Seroprevalence of and risk factors for Toxoplasma gondii in sheep raised in the Jaboticabal microregion, São Paulo State, Brazil. Res Vet Sci 88 104-106.

28. Pinheiro JW Jr, Mota RA, Oliveira AA, Faria EB, Gondim LF, et al. (2009) Prevalence and risk factors associated to infection by Toxoplasma gondii in ovine in the state of Alagoas, Brazil. Parasitol Res 105: 708-715.

29. Figliuolo LPC, Kasai N, Ragozo AMA, de Paula VSO, Dias RA, et al. (2004) Prevalence of anti-Toxoplasma gondii and anti-Neospora caninum antibodies in sheep from Sao Paulo State, Brazil. Vet Parasitol 124: 161-166.

30. Rossi GF, Cabral DD, Ribeiro DP, Pajuaba ACAM, Correa RR, et al. (2011) Evaluation of Toxoplasma gondii and Neospora caninum infections in sheep from Uberlândia, Minas Gerais State, Brazil, by different serological methods. Vet Parasitol 175: 252-259.

31. Tembue AA, Ramos RA, de Sousa TR, Albuquerque AR, da Costa AJ, et al. (2011) Serological survey of Neospora caninum in small ruminants from Pernambuco State, Brazil Rev Bras Parasitol Vet 20: 246-248.

32. Silva AV, Cunha ELP, Meireles LR, Gottschalk S, Mota RA, et al. (2003) Sheep and goat toxoplasmosis: soroepidemiological study in two regions in the State of Pernambuco, Brazil. Cienc Rural 33: 115-119. 
Citation: Oshiro LM, Reis FA, Dittrich RL, Cunha RC, Andreotti R (2015) Serology for Toxoplasmosis and Neosporosis in Ewes in the State of Mato Grosso Do Sul, Brazil. J Veterinar Sci Technol 6: 233. doi:10.4172/2157-7579.1000233

Page 5 of 5

33. Ueno TE, Gonçalves VS, Heinemann MB, Dilli TL, Akimoto BM, et al. (2009) Prevalence of Toxoplasma gondii and Neospora caninum infections in sheep from Federal District, central region of Brazil. Trop Anim Health Prod 41: 547 552 